\title{
Expression and secretion of human recombinant LIF by genetically modified mammalian cells
}

\author{
S. Yu. Rymar, T. A. Ruban, D. M. Irodov, V. A. Kordium \\ Institute of Molecular Biology and Genetics NAS of Ukraine \\ 150, Akademika Zabolotnoho Str., Kyiv, Ukraine, 03680 \\ s.y.rymar@imbg.org.ua
}

\begin{abstract}
Aim. The aim of this work was to express the human LIF gene in mammalian cells and to study the secretion of recombinant LIF into culture medium. Methods. Recombinant LIF was detected by Western blot analysis and immunoprecipitation in culture medium of CHO-K1, L-M (TK) (ins $\left.{ }^{+}\right), 293 \mathrm{~T}_{\text {cells, }}$ transfected with recombinant plasmids containing human LIF gene. Results. The recombi-nant plasmids. containing human gene LIF, were constructed. The cells of three (CHO-K1, L-M (TK $)\left(\right.$ ins $\left.^{+}\right)$, 293T) mammalian lines were transfected with these plasmids. It was shown that the transfected mammalian cells secreted recombinant human LIF which was characterized by variable degree of glycosylation including completely glycosylated form (approximately $68 \mathrm{kD}$ ). Conclusions. The conditioned medium of developed cell lines can be used as a source of human recombinant LIF for different purposes, including purification of human recombinant LIF and as an additional supplement for cell culturing.
\end{abstract}

Keywords: recombinant LIF, expression, secretion, transfection, cell lines.

Introduction. Leukemia inhibitory factor (LIF) is a polyfunctional cytokine of IL-6 family. It affects different tissues and types of cells, including hematopoietic, neural and muscle cells, hepatocytes, adipocytes, osteoblasts and osteoclasts. LIF affects proliferation of germ cells and maintenance of pluripotent embryonic stem cells. It plays a key role in the implantation of a blastocyst, participates in the hypothalamus-pituitary-adrenal axis activation, and development of pituitary, kidneys, energetic homeostasis, etc. [1].

The impact of LIF on the main processes in different cells is a reason to use this protein as a growth factor during cultivation of stem cells of

(c) Institute of Molecular Biology and Genetics NAS of Ukraine, 2011 various origin and their directed differentiation into cells of various types.

LIF is known as an absolutely necessary component of a medium, required to support pluripotency of mouse embryonic stem cells. These cells are widely used for investigations of pluripotency mechanisms and biology of embryonic stem cells [2, 3]. LIF supports the multiplication of human neural stem cells, providing their long-term self-renewal (up to 110 doublings) [4] and keeping their multipotent properties for a year [5]. It is also added into media for the cultivation of mesenchymal stem cells (MSC), that improves their osteogenetic differentiation [6,7], as well as for MSC differentiation into cardiomyocytes $[8,9]$. The non-glycosylated, Escherichia coli expressed, human recombinant LIF has a biological 
activity, which is manifested by its ability to induce differentiation of murine myeloid leukemic M1 cells [10]. It is used in investigations in vitro and in vivo, though the desired results are not always achievable in vivo [11]. One of the main reasons of such negative result is the lack of glycosylation of recombinant proteins. The glycosylation increases protein stability and its lifetime in bloodstream, influences resistance to proteases, antigenicity and specific activity which is important for therapeutic proteins [12]. This fact is the reason of searching for special ways to increase the level of glycosylation of recombinant proteins in the process of their expression in mammalian cells [13, 14]. For cell cultivation in vitro the purified recombinant growth factors, cytokines, and other biologically active molecules are added to the medium or conditioned media are used $[15,16]$. Inactivation of growth factors requires regular replacement of the medium. Therefore, other approaches to provide efficient microenvironment for the cultivated cells are elaborated too, in particular, using immobilized growth factors [17] and transgenic cell lines as feeder cells [18-20]. The development of transgenic cell lines of different origin allows solving a number of tasks, related to the study of a transgene effect on the recipient cell. Besides, expression of recombinant proteins in mammalian cells is a main source of producing glycosylated proteins. Thus, in $200770 \%$ of world production of therapeutic recombinant proteins were obtained in Chinese hamster cells [21]. Because of the significance of LIF for investigations in vivo and in vitro, the aim of this work was to express human recombinant LIF in the cells of transgenic mammalian cell lines and to study its secretion into the culture medium.

Materials and Methods. Plasmids $p U C 28$, pBluScrII $\left(K S^{+}\right)$, pEGFP-C1; strains of E. coli XL1, DH10B; cell lines CHO-K1 (Chinese hamster, ovary), $\mathrm{L}-\mathrm{M}\left(\mathrm{TK}^{-}\right)$(ins ${ }^{+}$) (mouse, subcutaneous connective tissue), transfected with recombinant plasmid, containing human insulin gene, and 293T, which is a variant of line HEK293 (human embryonic kidney), expressing large T-antigen SV40 and resistant to G418, were used in the work.

The isolation of plasmid DNA, treatment with restriction endonucleases, ligation, obtaining competent E. coli cells, analysis of recombinant plasmids were performed by standard methods [22].

The following primers were used to obtain cDNA LIF: 5'-TCTGAGGTTTCCTCCAAGG-3' and 5'-TGCTCAGCTTCATCACAGC-3';

5'-ATGAAGGTCTTGGCGGCAGG-3' and 5'-ACCTCCTGCTAGAAGGCCTG-3'.

cDNA of LIF gene was obtained by reverse transcription reaction according to the manufacturer instructions, using cDNA synthesis kit (Fermentas, Lithuania). PCR was performed in standard buffer conditions for Taq and Pfu polymerases using the optimal program in accordance with specific tasks.

Mammalian cells were transfected with recombinant plasmids using polyethyleneimine (PEI) [23]. Cells were kept with the complexes DNA-PEI for 1 hour. Selection of CHO-K1 cells, transfected with $p C 1-L$, was conducted using G418 $(200 \mathrm{mg} / \mathrm{ml})$. After transfection with $p C 1-I L$ the cells were selected with hygromycin $(200 \mathrm{Mg} / \mathrm{ml}) . \mathrm{L}-\mathrm{M}\left(\mathrm{TK}^{-}\right)\left(\mathrm{ins}^{+}\right)$and $293 \mathrm{~T}$ cells were transfected only with $p C 1-I L$, as they were resistant to G418. In starting experiments an optimal concentration of antibiotics required to kill host cells was determined.

The expression and secretion of LIF into culture medium were studied by Western-blot analysis and immunoprecipitation. The cells were grown on DMEM medium, containing $20 \%$ fetal calf serum, washed with DMEM (serum-free) three times, and then grown in the same medium during 1.5-2 days. Next, the culture medium was collected, proteins were precipitated by $10 \%$ solution of TCA in the presence of $0.015 \%$ sodium deoxycholate. After protein separation by SDS-PAGE [24] Western-blot analysis was performed in accordance with the online protocol of Millipore company (USA) (millipore.com/immunodetection /id3/westernblotting), using polyclonal anti-human LIF antibodies (developed in goat) and anti-goat IgG peroxidase conjugate (Sigma, USA).

Immunoprecipitation was performed according to the protocol of Abcam company (USA) (abcam.com/ps/ pdf/protocols/immunoprecipitation). $1 \mathrm{ml}$ of the conditioned DMEM medium, obtained after cultivation of $2.5 \cdot 10^{5}$ cells, was mixed with $3 \mathrm{mg}$ of primary antibodies and incubated for 4 hours while stirring at 4?C, then $70 \mathrm{Ml}$ of protein G-sepharose were 


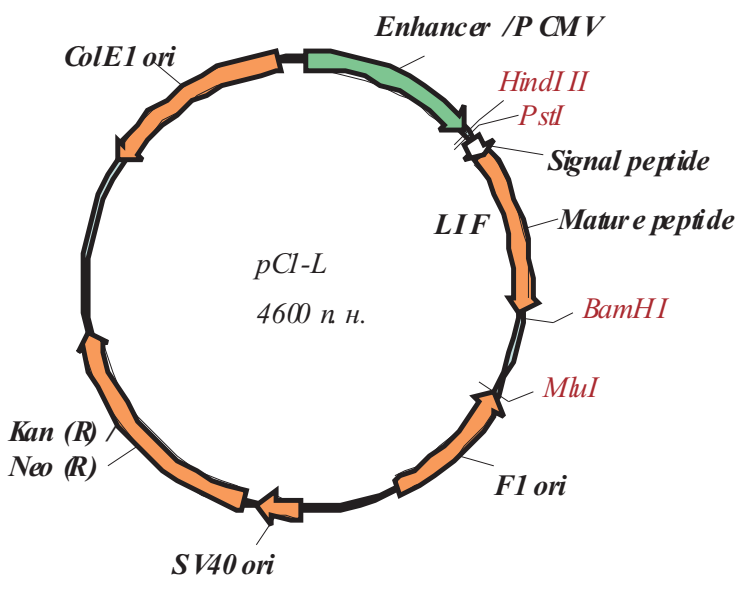

Fig.1 Physical maps of recombinant plasmids

added and incubated again (4?C, 4 hours). Samples were centrifuged, supernatant was removed and protein G-sepharose was washed three times with the following buffer: $50 \mathrm{mM}$ tris- $\mathrm{HCl}, \mathrm{pH} 8.0,150 \mathrm{mM}$ $\mathrm{NaCl}, 1 \% \mathrm{NP}-40,0.1 \%$ SDS. $25 \mathrm{ml}$ of loading buffer were added to protein G-sepharose and boiled ( $5 \mathrm{~min}$ ). Western-blot analysis was performed after electrophoresis in SDS-PAGE..

Results and Discussion. At first the LIF coding sequence with signal sequence [Human LIF gene, coding LIF with signal peptide, was cloned via RT-PCR methodology using mRNA, extracted from human placenta, and corresponding primers. LIF cDNA, amplified in PCR, was cloned in pBluScrII $\left(\mathrm{KS}^{+}\right)$, and its nucleotide sequence was confirmed by sequencing. Two plasmids $-p C 1-L$ and $p C 1-I L$ (Fig.1) - were constructed based on the expression vector for mammalian cells $p E G F P-C 1$ (Clontech, USA). LIF gene was introduced to $p C 1-L$ under the control of cytomegalovirus promoter, while a fragment of DNA, containing IRES (internal ribosome entry site) of encephalomyocarditis virus and hygromycin resistance gene were introduced into $p C 1-I L$.

The expression of $L I F$ gene, inserted in these plasmids, in eukaryotic cells should result in secretion of the glycosylated protein. LIF has six sites of glycosylation [25]. The molecular weight (m.w.) of the protein is in the range from $32 \mathrm{kDa}$ to $73 \mathrm{kDa}$ depending on the glycosylation degree. Western-blot analysis of the media, conditioned by the cells of three cell lines, transfected with recombinant plasmids,

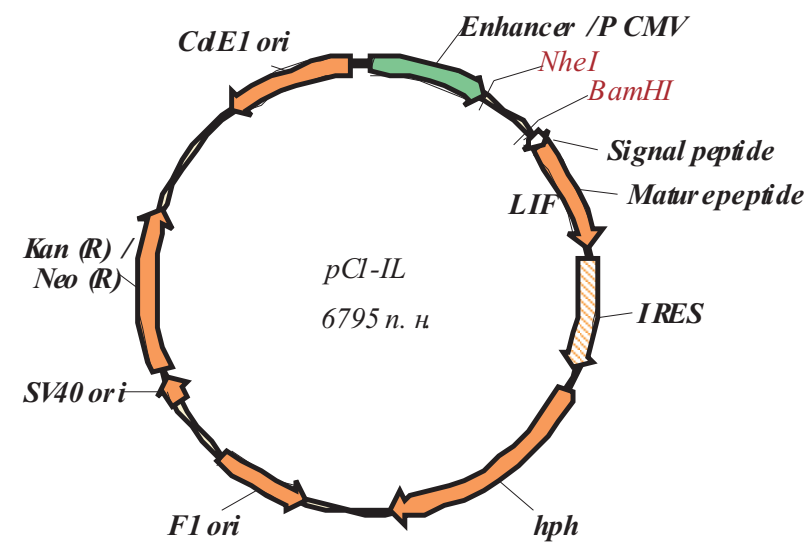

showed that they secreted LIF which was likely glycosylated to a variable degree. The proteins with m.w. about $30 \mathrm{kDa}, 55 \mathrm{kDa}$ and $68-72 \mathrm{kDA}$ were identified (Fig.2-4).

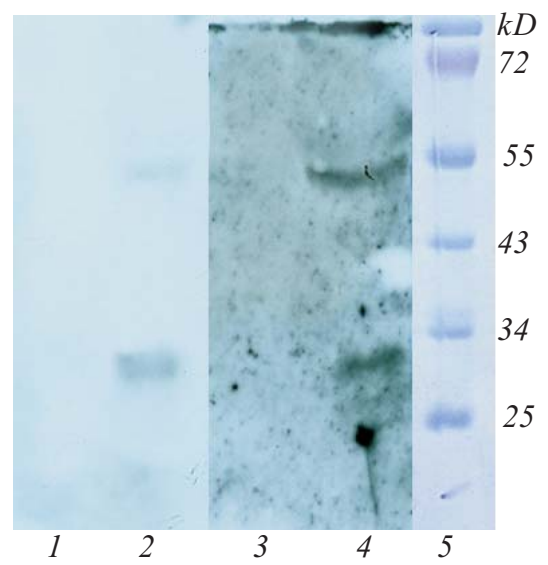

Fig. 2 Western-blot analysis of conditioned media ( $1^{\text {st }}$ passage cells $)$ : 1 CHO-K1 (control, transfection with the vector, serum- free DMEM , 24 hours); 2 - CHO-K1 (transfection with $p C 1-L$, serum-free DMEM, 24 hours); 3 - CHO-K1 (control, transfection with the vector, serum-free DMEM, 48 hours); 4 - CHO-K1 (transfection with $p C l-L$, serum-free DMEM , 48 hours); 5 - molecular weight marker, $\mathrm{kDa}$

The protein with the highest molecular weight form likely corresponds to completely glycosylated protein. Bovine serum albumin, presented in the serum, interfered with the visualization of completely glycosylated LIF. Due to this fact the LIF secretion was studied via cultivation of washed cells in serum-free DMEM. Under these conditions the cells lost their 


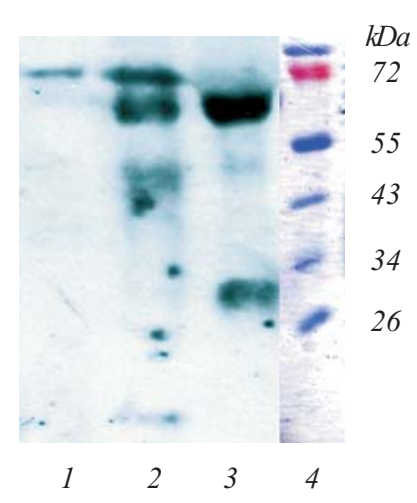

Fig.3 Western-blot analysis of conditioned media (cells of $2^{\text {nd }}$ and $3^{\text {rd }}$ passages, cultivated in serum-free DMEM for 48 hours); 1 - CHO-K1 (control, transfection with the 26 vector); 2 - CHO-K1 (transfection with $p C 1-L) ; 3-\mathrm{CHO}-\mathrm{K} 1$ (transfection with $p C 1-I L) ; 4$ molecular weight marker, $\mathrm{kDa}$

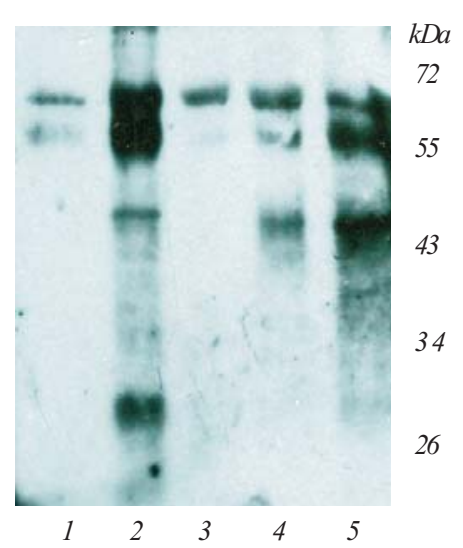

viability in 2-3 days and the level of expression of cellular proteins including recombinant protein decreased correspondingly. The viability of L-M (TK $\left.{ }^{-}\right)$ (ins $\left.{ }^{+}\right)$line cells, producing human insulin, was higher in comparison with CHO-K1 and 293T. Besides, the controls may have positive signals specified by endogenous LIF because the degree of homology of human LIF with murine one is $79 \%$. According to the analysis of experimental data from different laboratories, the molecular mass of human LIF isolated from various cells is diverse. For instance, the recombinant LIF with m.w. about $45 \mathrm{kDa}$ was expressed in the Chinese hamster cells [26]. LIF with m.w. $73 \mathrm{kDa}$ was isolated from the conditioned medium of the bladder carcinoma cell line 5637 [27]. Other authors isolated LIF with m.w. $43 \mathrm{kDa}$ from the same source [28], LIF with m.w. $38 \mathrm{kDa}$ was obtained from the conditioned medium of T-lymphocytes [29].
For Western-blot analysis LIF, secreted into conditioned medium and concentrated with immunoprecipitation using protein G-sepharose, was used. The results obtained with genetically modified lines CHO-K1, L-M $\left(\mathrm{TK}^{-}\right)\left(\right.$ins $\left.^{+}\right)$and 293T, are presented in Fig.5. The Western-blot analysis revealed that mobility of some forms of LIF (in particular with m.w. about $30 \mathrm{kDa}$ and $55 \mathrm{kDa}$ ) coincided with that of light and heavy chains of immunoglobulins, added to the sample during immunoprecipitation. It resulted in masking some forms of LIF by immunoglobulins. The level of signals derived from the light and heavy chains of immunoglobulins in the immunoprecipitation of conditioned medium by the cells, transfected with vector plasmids (without $L I F$ gene), was significantly lower. There was an additional intensive band, corresponding to the protein with m.w. $65-68 \mathrm{kDa}$, which was likely a completely glycosylated form of LIF, and a less intensive band, corresponding to the protein with m.w. about $48 \mathrm{kDa}$. The LIF expression in cells CHO-K1 (Fig.3, 4) transfected with $p C 1-L$ using G418 selection was more efficient than LIF expression in cells, transfected with $p C 1-I L$ using hygromycin selection. The efficiency of LIF expression in L-M $\left(\mathrm{TK}^{-}\right)\left(\right.$ins $\left.^{+}\right)$cells, transfected with $p C 1-I L$, was

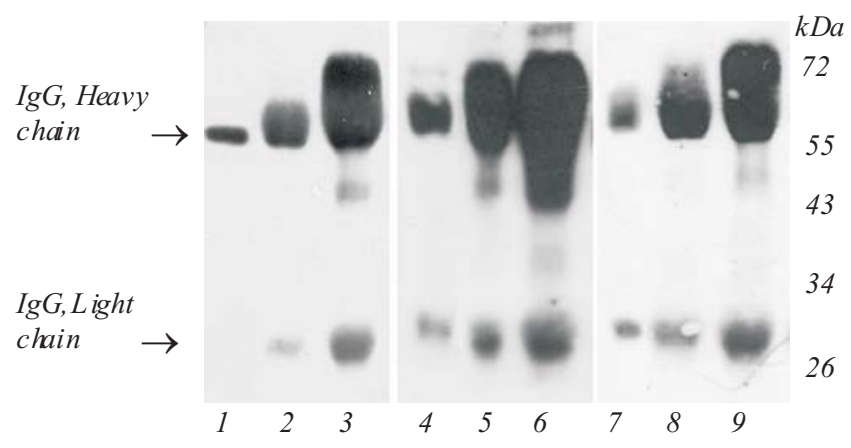

Fig.5 Determination of LIF in conditioned media (immunoprecipitation) (cells of $2^{\text {nd }}-4^{\text {th }}$ passages, cultivated in serum-free DMEM for 48 hours, except for L-M $\left(\mathrm{TK}^{-}\right)\left(\mathrm{ins}^{+}\right)$): 1 control of immunoprecipitation (immunoprecipitation without medium); $2-293$ T (control, transfection with the vector); 3-293T (transfection with $p C 1-I L$ ); 4 - CHO-K1 (control, transfection with the vector); 5 - CHO-K1 (transfection with $p C 1-I L$ ); $6-\mathrm{CHO}-\mathrm{K} 1$ (transfection with $p C 1-L) ; 7-\mathrm{L}-\mathrm{M} \quad\left(\mathrm{TK}^{-}\right)\left(\right.$ins $\left.^{+}\right)$(control, transfection with the vector); $8-\mathrm{L}-\mathrm{M}\left(\mathrm{TK}^{-}\right)\left(\mathrm{ins}^{+}\right)$(transfection with $p C 1-I L$, serum-free DMEM, 15 hours); $9-\mathrm{L}-\mathrm{M}\left(\mathrm{TK}^{-}\right)\left(\mathrm{ins}^{+}\right)$ (transfection with $p C 1-I L$, serum- free DMEM, 48 hours); 10 molecular weight marker, $\mathrm{kDa}$ 
sufficiently high like that in CHO-K1 cells, transfected with $p C 1-L)$ ( Fig.4). It may be explained by the fact that the inhibition of metabolism in insulin-producing cells in serum-free media is weaker than in CHO-K1 and 293 T cells.

Conclusions. The recombinant plasmids $p C 1-L$ and $p C 1-I L$, constructed by us, provide expression and secretion of human recombinant LIF in the medium of three mammalian line cells (two murine and one human) transfected with these plasmids. The recombinant human LIF produced with mammalian transgenic cells is glycosylated to different degree, likely including completely glycosylated form. The medium conditioned by genetically modified cells may be used as a source of LIF for growth of different cells requiring this growth factor as well as for its isolation.

Acnowlegment. The authors thank E. K. Toporova for kindly provided L-M ( $\left.\mathrm{TK}^{-}\right)\left(\right.$ins $\left.^{+}\right)$cell line.

\section{C. Е. Рыммарь, Т. А. Рубан, Д. М. Иродов, В. А. Кордюм}

Экспрессия и секреция рекомбинантного белка

LIF человека генетически модифицированными клетками млекопитающих

Институт молекулярной биологии и генетики НАН Украины Ул. Академика Заболотного, 150, Киев, Украина, 03680

\section{Резюме}

Цель работы состояла в получении экспрессии гена LIF челове ка в генетически модифицированных клетках млекопитающих и изучении секречии рекомбинантного белка этими клетками в культуральную среду. Методы. Для выявления рекомбинантного LIF в кондиционированной среде, полученной в результате культивирования клеток, трансфецированных рекомбинантными плазмидами, содержашими ген LIF, использовали Вестерн-блот-анализ и иммунопреципитацию. Результаты. Сконструированные рекомбинантные плазмиды обеспечивают експрессию и секречию рекомби- нантного LIF человека клетками трех линий (CHO-K1, L-M(TK')(ins $\left.{ }^{+}\right)$и 293T), трансфецированными этими плазмидами. Степень гликозилирования продуцируемого такими клетками рекомбинантного LIF варьирует, при этом наблюдается секреция полностью гликозилированного LIF (с молекулярной массой около 68 кДа). Выводы. Кондииионированную среду, полученную вследствие культивирования трансфецированных клеток, можно использовать как источник LIF человека для культивирования клеток, нуждаюшихся в этом ростовом факторе, и для его выделения в чистом виде.

Ключевые слова: рекомбинантный LIF, экспрессия, секреиия, трансфекция,клеточные линии

\section{С. Ю. Римар, Т. А. Рубан, Д. М. Іродов, В. А. Кордюм}

Експресія і секреція рекомбінантного білка LIF людини генетично модифікованими клітинами ссавців

Резюме

Мета. Мета роботи полягала в одержанні експресії гена LIF людини в генетично модифікованих клітинах ссавиів і вивченні секреції рекомбінантного білка ичими клітинами в культуральне середовище. Методи. Для визначення рекомбінантного LIF в кондиціонованому середовищі, одержаному в результаті культивування клітин, трансфекованих рекомбінантними плазмідами, що містять ген LIF, використовували Вестернблот аналіз та імунопрециипітацію. Результати. Сконструйовані рекомбінантні плазміди забезпечують експресію і секреціюю рекомбінантного LIF людини клітинами трьох ліній (CHOK1, L-M(TK $)\left(\right.$ ins $\left.^{+}\right)$і 293T), трансфекованих циими плазмідами. Ступінь глікозилювання рекомбінантного LIF, продукованого такими клітинами, варіює, при иьому спостерігається секреція повністю глікозильованого LIF (з молекулярною масою близько 68 кДа). Висновки. Кондиціоноване середовище, одержане внаслідок культивування трансфекованих клітин, можна використовувати як джерело LIF людини для культивування клітин, яким потрібен цей ростовий фактор, а також для його виділення в очищеному стані.

Ключові слова: рекомбінантний LIF, експресія, секречія, трансфекиія, клітинні лінії.

\section{СПИСОК ЛИТЕРАТУРЫ}

1. Auernhammer C. J., Melmed S. Leukemia inhibitory factorneuroimmune modulator of endocrine function // Endocrin. Revs.-2000.-21, N 3.-P. 313-345.

2. Matsuda T., Nakamura T., Nakao K. T., Katsuki M., Heike T., Yokota T. STAT3 activation is sufficient to maintain an undifferentiated state of mouse embryonic stem cells // EMBO J.-1999.-18, N 15.-P. 4261-4269.

3. Zandstra P. W., Le H. V., Daley G. Q., Griffith L. G., Lauffenburger $D$. A. Leukemia inhibitory factor (LIF) concentration modulates embryonic stem cell self-renewal and differentiation independently of proliferation // Biotechnol. Bioeng.2000.-69, N 6.-P. 607-617.

4. Wright L. S., Li J., Caldwell M. A., Wallace K., Johnson J. A. Svendsen $C . N$. Gene expression in human neural stem cells: effects of leukemia inhibitory factor // J. Neurochem.-2003.86, N 1.-P. 179-195.

5. Carpentera M. K., Cuib X., Hua Z., Jacksona J., Shermana S., Seigerc A., Wahlberga L. U. In vitro expansion of a multipotent population of human neural progenitor cells // Exp. Neurol.-1999.-158, N 2.-P. 265-278.

6. Pat. USA 7109032. Serum-free medium for mesenchymal stem cells / R. Cancedda, B. Dozin // Publ. 09/19/2006.

7. Pat. USA 6432711. Embryonic stem cells capable of differentiating into desired cell lines / J. H. Dinsmore, J. Ratliff // Publ. $8 / 13 / 2002$

8. Pat. USA 7534607. Method of producing cardiomyocytes from mesenchymal stem cells / W. Chen, S. Lin // Publ. 19.05.2009.

9. Dimaracis I., Levicar N., Nihoyannopoulos P. In vitro stem cell differentiation into cardiomyocytes: Part 1.Culture medi- 
um and growth factors // J. Cardiothor. Renal Res.-2006.-1, N 2.-P. 107-114.

10. Gearing P. D., Gough N. M., King J. A., Hilton D. J., Nicola N. A., Simpson R. J., Nice E. C., Kelso A., MetcalfD. Molecular cloning and expression of cDNA encoding a murine myeloid leukaemia inhibitory factor (LIF) // EMBO J.-1987.-6, N 13.-P. 3995-4002.

11. Brinsden P. R., Alam V., De Moustier B., Engrand P. Recombinant human leukemia inhibitory factor does not improve implantation and pregnancy outcomes after assisted reproductive techniques in women with recurrent for unexplained implantation failure // Fertil. Steri1.-2009.-91, N 4.-P. 14451447.

12. Hossler P., Khattak S. F., Jian Z. Optimal and consistent protein glycosylation in mammalian cell culture// Glycobiology.-2009.-19, N 9.-P. 936-949.

13. Pat. USA 6673575. Method for preparing polypeptides with appropriate glycosilation / F. Reinhard, E. Horst, W. Claus // Publ. 10.06.1999.

14. Bork K., Horstkorte R., Weidemann W. Increasing the sialylation of therapeutic glycoproteins: The potential of the sialic acid biosynthetic pathway // J. Pharmaceutic. Sci.-2009.-98, N 10.-P. 3499-3508.

15. Pat. USA 7118746. Conditioned cell culture medium compositions and methods of use / G. K. Naughton, D. L. Horwitz, M. A. Applegate, J. Zeltinger, J. N. Mansbridge, A. Kern, L. K. Landeen, A. Ratcliffe, R. E. Pinney // Publ.10.10.2006.

16. Pat. USA 7723105. Conditioned cell culture medium, method to obtained the same and use of it for maintenance, proliferation and differentiation of mammalian cells / V. Bordoni, T. Alonzi, M. Tripodi // Publ. 5/25/2010.

17. Makino H., Hasuda H., Ito Y. Immobilization of leukemia inhibitory factor (LIF) to culture murine embryonic stem cells // J. Biosci. Bioeng.-2004.-98, N 5.-P. 374-379.

18. Kameda T., Sugiyama T. Application of genetically modified feeder cells for culture of keratinocytes // Meth. Mol. Biol.2005.-289, N 1.-P. 29-38.

19. Sidhu K. S., Lie K. H., Tuch B. E. Transgenic human fetal fibroblasts as feeder layer for human embryonic stem cell lineage selection // Stem Cells Dev.-2006.-15, N 5.-P. 741-747.

20. Unger C., Gao S., Cohen M., Jaconi M., Bergstrom R., Holm F., Galan A., Sanchez E., Irion P., Dubuisson J. B., Giry-Laterriere M., Salmon P., Simon C., Hovatta O., Feki A. Immor- talized human skin fibroblast feeder cells support growth and maintenance of both human embryonic and induced pluripotent stem cells // Hum. Reprod.-2009.-24, N 10.-P. $2567-$ 2581.

21. Jayapal K. P., Wlaschin K. F., Yap M. G. S., Hu W.-S. Recombinant protein therapeutics from $\mathrm{CHO}$ cells -20 years and counting// Chem. Eng. Prog.-2007.-103, N 7.-P. 40-47.

22. Maniatis T., SambrookJ., Fritsch E. F. Molecular cloning: A laboratory manual.-New York: Cold Spring Harbor Lab. publ., 1982.-545 p.

23. Geisse S., Henke M. Large-scale transient transfection of mammalian cells: a newly emerging attractive option for recombinant protein production // J. Struct. Funct. Genomics.2005.-6, N 2-3.-P. 165-170.

24. Laemmli U. K. Cleavage of structural proteins during the assembly of the head of bacteriophage T4 // Nature.-1970.227, N 5259.-P. 680-685.

25. Schmelzer C. H., Harris R. J., Butler D., Yedinak C. M., Wagner K. L., Burton L. E. Glycosylation pattern and disulfide assignment of recombinant human differentiation-stimulating factor // Arch. Biochem. Biophys.-1993.-302, N 2.-P. 484-489.

26. Schmelzer C. H., Burton L. E., Tamony C. M. Purification and partial characterization of recombinant human differentiation-stimulating factor // Protein Exp. Purific.-1990.-1, N 1.P. 54-62.

27. Pat. USA 004098. Leukemia inhibitory factor/ N. M. Gough, T. A. Willson, D. Metcalf, D. J. Hilton, E. C. Nice, N. A. Nicola, R. J. Simpson, J. A. King, D. P. Gearing // Publ. 02.01.2003.

28. Gascan H., Anegon I., Praloran V., Naulet J., Godard A., Soulillou J. P., Jacques Y. Constitutive production of human interleukin for DA cells/leukemia inhibitory factor by human tumor cell lines derived from various tissues // J. Immunol.1990.-144, N 7.-P. 2592-2598.

29. Godard A., Gascan H., Naulet J., Peyrat M. A., Jacques Y., Soulillou J. P., Moreau J. F. Biochemical characterization and purification of HILDA, a human lymphokine active on eosi- nophils and bone marrow cells // Blood.-1988.-71, N 6.- P. 1618-1623.
UDC $571.29+57.085 .23$ Received 21.10.10 